Far Eastern Entomologist

\begin{tabular}{lll}
\hline Number 437: 16-23 & $\begin{array}{l}\text { ISSN 1026-051X (print edition) } \\
\text { ISSN 2713-2196 (online edition) }\end{array}$ & September 2021 \\
\hline
\end{tabular}

https://doi.org/10.25221/fee.437.4

http://zoobank.org/References/FB0DD434-F2FB-433F-921D-7D565F1BF42C

\title{
FIRST RECORDS OF THE CHRYSIS LEACHII GROUP FROM SUB- SAHARAN AFRICA, WITH DESCRIPTION OF A NEW SPECIES (HYMENOPTERA, CHRYSIDIDAE)
}

\author{
P. Rosa \\ Laboratory of Zoology, Institute of Biosciences, University of Mons, Place du Parc, 20, \\ 7000, Mons, Belgium.E-mail: paolo.rosa@umons.ac.be
}

Summary. The Chrysis leachii species group is recorded from sub-Saharan Africa for the first time with two species: Chrysis rasnitsyni sp. n. (from Central African Republic, Ivory Coast, and Senegal) and Chrysis nilensis Linsenmaier, 1959 (Ivory Coast, Sudan). The lectotype of Chrysis leachi var. cyanea du Buysson, 1908 is designated. Illustrations of the two species are presented.

Key words: cuckoo wasps, Chrysidini, taxonomy, new species, description, lectotype designation, Afrotropical region.

П. Роза. Первые находки группы Chrysis leachii из Африки к югу от Сахары с описанием нового вида (Hymenoptera, Chrysididae) // Дальневосточный энтомолог. 2021. N 437. С. 16-23.

Резюме. Впервые из Африки к югу от Сахары приводятся два вида группы Chrysis leachii: Chrysis rasnitsyni sp. n. (Центральноафриканская Республика, Кот-д'Ивуар и Сенегал) и Chrysis nilensis Linsenmaier, 1959 (Кот-д'Ивуар и Судан). Обозначен лектотип Chrysis leachi var. cyanea du Buysson, 1908. Даны иллюстрации обоих видов.

\section{INTRODUCTION}

Linsenmaier (1959) established the Chrysis leachii species group based on 15 WestPalaearctic species. He later described another three North African species (1968) and Kimsey \& Bohart (1991) added a Central Asia species, Chrysis infantula Semenov-TianShanskij, 1967. After the publication of the world catalogue by Kimsey \& Bohart (1991), another ten species were described in this species group: four from the Canary Islands $(C$. atrocomitata, C. globiscutella, C. magnifacialis, and C. umbofacialis by Linsenmaier 1993); one from the Arabian Peninsula (Chrysis hattaensis Linsenmaier, 1994); one from Tunisia (C. wolfi Linsenmaier, 1999); two from the Mediterranean Basin (C. alcudiae Reder \& Arens, 2012 and C. aegeriaca Arens, 2016), one from southern Russia (Chrysis lyda Rosa in Rosa et al., 2017b) and another one from Siberia (C. proauriceps Rosa in Rosa et al., 2017a). Based on the known species, the $C$. leachii group was supposed to have a West Palaearctic chorotype only (Kimsey \& Bohart, 1991). In fact, no taxa have been recorded for sub-Saharan Africa, so far (Madl \& Rosa, 2012). 
During the examination of the Linsenmaier collection housed at the Natur-Museum in Luzern (Switzerland) (Rosa et al., 2015), we discovered that the Swiss author owned twenty Afrotropical specimens of this group identified as Chrysis annectilinea, from Ivory Coast, and $C$. afroleachii, from Ivory Coast and Sudan. Although these specimens were labelled as types, their description was never published and they must be considered as nomina in collection. More recently, Marek and Jiří Halada (České Budějovice, Czech Republic) collected another nine specimens of Linsenmaier's annectilinea from Senegal and Central African Republic.

In the present article we describe a new African species in the Chrysis leachii group and report the presence of a second one, namely Chrysis nilensis Linsenmaier, 1959, thus extending the chorological distribution of this group to the Afrotropical realm. We also designate the lectotype of the second African species, C. leachi var. cyanea du Buysson, 1908 nec Linnaeus, 1758, currently C. nilensis Linsenmaier, 1959.

\section{MATERIAL AND METHODS}

Holotype and paratypes of the new species are deposited at the Natur-Museum, Luzern (Switzerland, NMLU). Other paratypes are deposited in the private collection of the author and in the private collection of Marek Halada (České Budějovice, Czeck Republic, MHC). Specimens were studied and photographed with a Togal SCZ microscope connected to a Nikon D80 and stacked with the software Combine ZP. Pictures of the male of C. rasnitsyni were taken with Canon EOS 40D and EOS 7D with Canon 100 and MPE 65 macro lenses.

Morphological terminology follows Lanes et al. (2020) and Kimsey \& Bohart (1991). Abbreviations as follows: F1, F2, F3, etc. = flagellomeres 1, 2, 3, etc., respectively; $1 / \mathrm{w}=$ length/width; $\mathrm{MOD}=$ anterior ocellus diameter; $\mathrm{MS}=$ malar space, the shortest distance between base of mandible and lower margin of compound eye; $\mathrm{OOL}=$ the shortest distance between posterior ocellus and compound eye; $\mathrm{P}=$ pedicel; $\mathrm{PD}=$ puncture diameter; $\mathrm{POL}=$ the shortest distance between posterior ocelli. Museum acronyms: Muséum National d'Histoire Naturelle, Paris, France (MNHN); Naturhistorisches Museum Wien, Vienna, Austria (NHMW).

\section{TAXONOMY}

Subfamily Chrysidinae Latreille, 1802

Tribe Chrysidini Latreille, 1802

Genus Chrysis Linnaeus, 1761

Chrysis Linnaeus, 1761: 414. Type species: Sphex ignita Linnaeus, 1758 [= Chrysis ignita (Linnaeus, 1758)], by subsequent designation of Latreille, 1810: 437.

\section{Chrysis leachii species group}

Chrysis (Chrysis) leachii group: Linsenmaier 1959: 92 (key to species group); 117-118 (diagnosis, keys), 190 (catalogue of the species); 1999: 161 (diagnosis).

Chrysis succincta-leachii subgroup: 364 (diagnosis, host, discussion).

DIAGNOSIS. Very small to small species $(2.5-5.0 \mathrm{~mm})$, usually brightly coloured, with apex of third metasomal tergum edentate or with short median tooth, sometimes lanceolate, rarely with blunt angles at sides of apical margin (in Chrysis excursa Linsenmaier, 1959 medially notched, yet the placement of this species in the leachii group must be confirmed); malar spaces short and strongly convergent; scapal basin broadly microridged in both sexes; 
transverse frontal carina faint; black spots on sternum II medium (covering about half segment length) to large (covering $2 / 3$ rds of segment length), subsquare or subrectangular, separated by a narrow metallic line.

REMARKS. The Chrysis leachii group is a small group of homogeneous species, with similar size, habitus, and colour pattern, with few exceptions. It is closely related to the $C$. succincta group, however, females can be immediately separated by the scapal basin broadly microridged (medially polished and laterally micropunctate in C. succincta group). It may be difficult for beginners to identify males of some species; in fact, they can be confused with small members of the C. succincta group because of their greenish body colour and the simple apex of third tergum. In this case, a combination of diagnostic characters must be taken into consideration, e.g. the presence/absence of the frontal carina, the shape of the black spots on second sternum, and the shape of the genital capsule. Apart from species of the Canaries Islands, only two species have both sexes with a completely green body: Chrysis nilensis Linsenmaier, 1959 (Fig. 3) and C. infantula Semenov-Tian-Shanskij, 1967. Kimsey \& Bohart (1991) classified the C. leachii group as a subgroup of the C. succincta group; we follow Linsenmaier's $(1959,1999)$ classification, which was recently supported by phylogenetic analysis (Pauli et al., 2019).

HOSTS. Species of the family Crabronidae, genus Miscophus Jurine, 1807 and Diodontus Curtis, 1834 (Linsenmaier, 1959; Rosa, 2006; Gert et al., 2010).

Chrysis rasnitsyni Rosa, sp. n.

http://zoobank.org/NomenclaturalActs/DAE96265-95F4-4C01-921D-A78E6FD44E3C

Figs $1 \mathrm{~A}-\mathrm{B}, 2 \mathrm{~A}-\mathrm{D}, 3 \mathrm{~A}-\mathrm{E}$

TYPE MATERIAL. Holotype - + , Ivory Coast: Denguélé, Odienné 20.IV 1980, [leg. W. Perraudin], coll. Linsenmaier (NMLU). Paratypes: same locality, collector and depository:

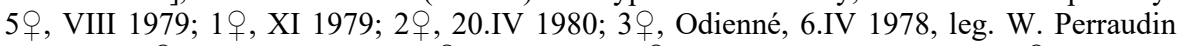
(NMLU); 2 , idem, 9.IV 1980; 1ㅇ, 17.V 1980; 2, idem, XI 1980. Senegal: $3+, 10 \mathrm{~km} \mathrm{E}$ of Medina Gounas, $13^{\circ} 08.05^{\prime} \mathrm{N} 13^{\circ} 42.03^{\prime} \mathrm{W}, 25 . \mathrm{VI}$ 2004, leg. M. Halada (MHC); 2 ㅇ, $15 \mathrm{~km}$ E of Velingara, 28.VI 2004, leg. M. Halada (MHC); $1 \mathrm{O}^{\lambda}, 70 \mathrm{~km}$ of W Tambacounda, $13^{\circ} 57.39^{\prime} \mathrm{N} 14^{\circ} 15.92^{\prime} \mathrm{W}, 29$.VI 2004, leg. M. Halada (MHC). Central African Republic: 1 , $60 \mathrm{~km}$ SE of Bouar, $05^{\circ} 42^{\prime} \mathrm{N} 16^{\circ} 00^{\prime} \mathrm{E}$, 30.III 2010, leg. J. Halada (MHC); $20^{\lambda}$, KoukorouBamingui Reserve, $07^{\circ} 15^{\prime} \mathrm{N} 20^{\circ} 03^{\prime} \mathrm{E}, 20 . \mathrm{IV} 2010$, leg. J. Halada (MHC).

DESCRIPTION. FEMALE. Body length: $4.5 \mathrm{~mm}$.

Head. OOL $1.7 \times$ MOD; POL $2.6 \times$ MOD; MS $1.5 \times$ MOD; relative length of P: F1: F2: $\mathrm{F} 3=1.0: 1.3: 0.7: 0.6$. Frons between scapal basin and anterior ocellus with dense, polygonal, large (about 0.6-0.8 $\times$ MOD) and contiguous punctures, without polished interspaces; punctures arranged radially around anterior ocellus (Fig. 1); head posterior to ocelli with smaller punctures and narrow interspaces; with small punctures aligned below eye; transverse frontal carina faint; scapal basin deep, with median narrowing, polished below frontal declivity, with sharp ridges, shallower along longitudinal midline; face between scapal basin and eye margin with large, contiguous punctures (Fig. 2B); genal carina straight, sharp, fully developed from mid eye to mandibular insertion; malar spaces relatively long $(1.3 \times \mathrm{MOD})$; subantennal space extremely short, $0.5 \times \mathrm{MOD}$; apex of clypeus with thin brown rim.

Mesosoma. Medial pronotal line large and elongate, reaching posterior margin of pronotum (Fig. 1A); pronotum as long as mesoscutellum, with deep, large punctures, as large as those on frons, rounded and with narrow, polished interspaces; mesoscutum with larger punctures on median area; notauli formed by deep, large foveae, with diameter similar to larger punctures; parapsidal signum almost faint, its area indicated by darker colour; mesoscutellum with irregular sized punctures; mesoscutellar-metanotal suture unusual, formed by deep, longitudinally elongate punctures, particularly elongate at sides, toward metanotal trough; 
metanotum punctures similar to scutellum; posterior propodeal projections slightly divergent, covered by deep, dense, small punctures; mesopleuron with large punctures, episternal sulcus formed by large confluent foveae, as well as scrobal sulcus.

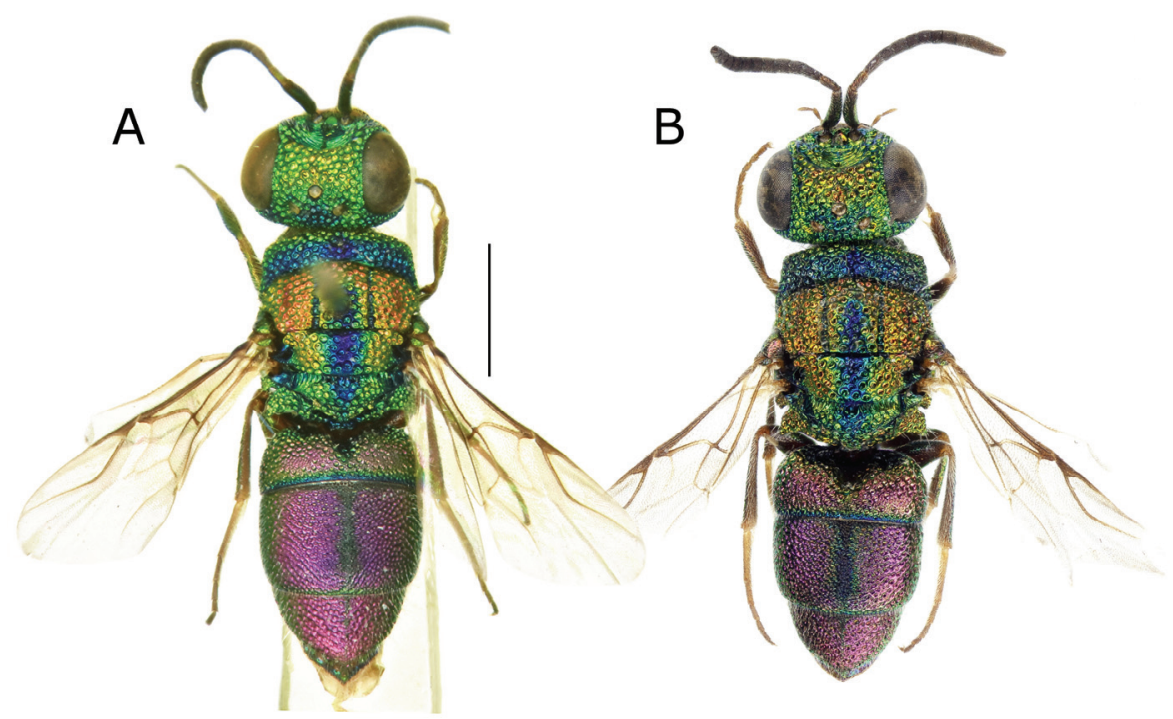

Fig. 1. Chrysis rasnitsyni sp. n., habitus, dorsal view: A - female from Ivory Coast; B male from Central African Rep. Scale bar $1.0 \mathrm{~mm}$.

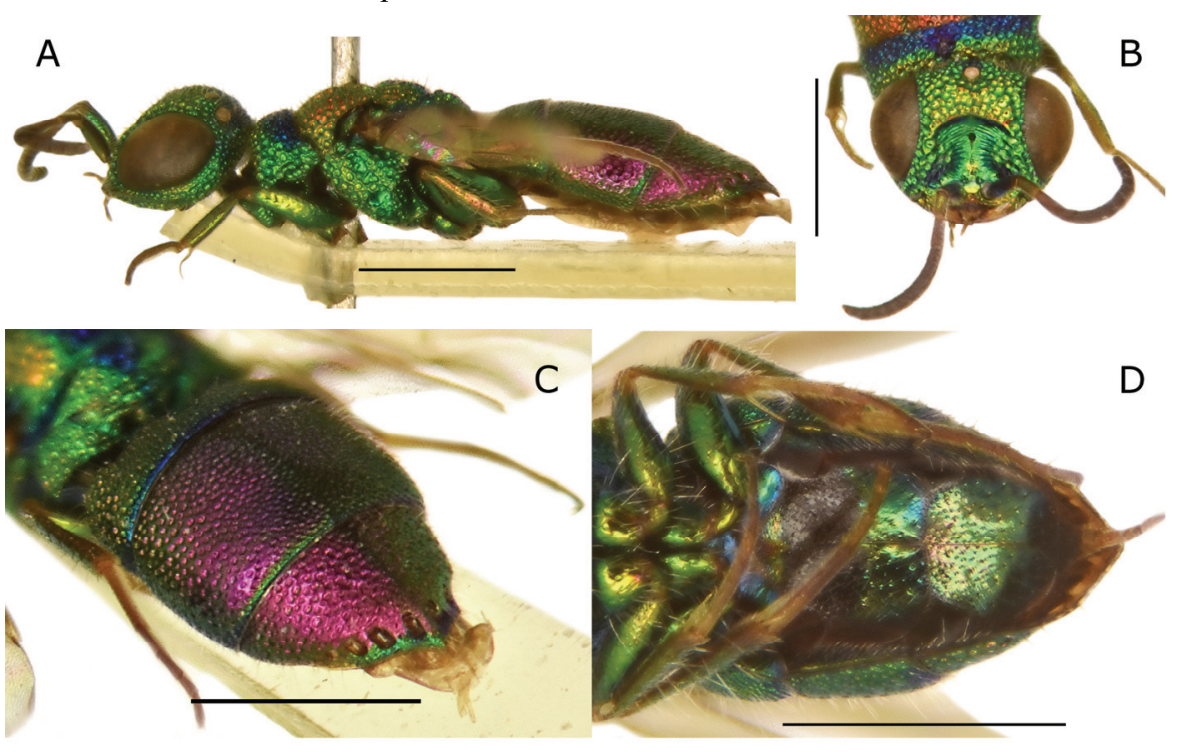

Fig. 2. Chrysis rasnitsyni sp. n., female: A - habitus, lateral view; B - head, frontal view; $\mathrm{C}$ - metasoma, postero-lateral view; D - metasoma, ventral view. Scale bars $1.0 \mathrm{~mm}$. 
Metasoma. Tergum I with distinct double punctation, with deep, large punctures and interspaces densely punctate by small punctures (Fig. 1A); largest punctures smaller than those on mesonotum and metanotum; antero-median concavity deep and wide; tergum II with dense, even punctures dorsally, sparser on segment sides (Fig. 2A); median longitudinal carina on terga II-III indicated by non-metallic black line; tergum III without slight pre pit swelling; pits of pit row small, deep, longitudinally elongate (Fig. 2C); tergum III, in dorsal view, triangular (Fig. 1), with sharp median tooth (Fig. 2C); black spots on sternum II square, as long as half of segment length, posteriorly separated by thin metallic line (Fig. 2D).

Colour. Head metallic green with feeble golden reflections; pronotum dorsally blue, anteriorly and laterally green; mesonotum red to orange, metanotum and propodeum green; mesoscutum and metanotum with large, median, longitudinal, blue line; metasoma purple with posterior margin of each tergum green to blue, including the apical margin of third tergum; scape and pedicel green; flagellomeres dark brown; tegulae metallic green; wings hyaline with light brown nervures; legs green, meso- and metalegs red on outern side; sterna metallic green.

Variability. Specimens from Senegal are less brightly coloured.

MALE. Similar to female (Figs 1B, 3A-E), with dimorphic apical margin of third metasomal tergum less pointed.

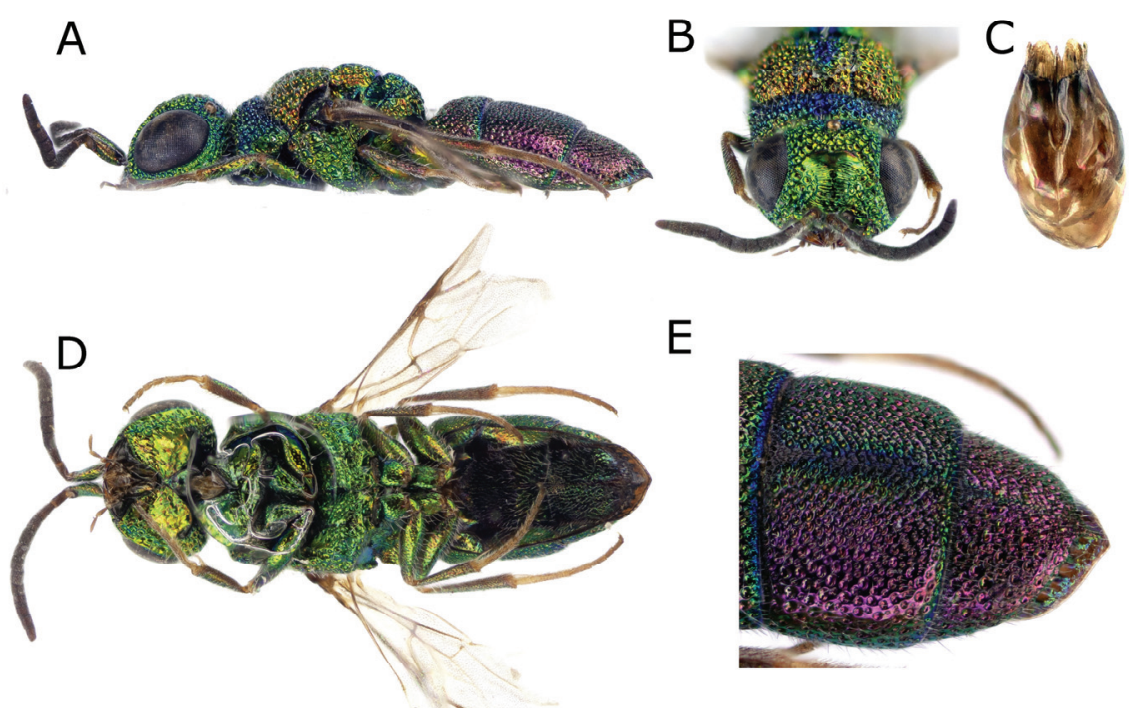

Fig. 3. Chrysis rasnitsyni sp. n., male from Central African Republic: A - habitus, lateral view; B - head, frontal view; C - genital capsule; D - habitus, ventral view; E - metasoma, dorso-lateral view. Scale bars $1.0 \mathrm{~mm}$.

DIAGNOSIS. Chrysis rasnitsyni $\mathrm{sp} . \mathrm{n}$. is easily recognisable in the C. leachii group for several diagnostic features: unique body colouration, with blue median line from mesoscutum to scutellum and purple metasoma; large, deep and dense punctures on head and mesosoma; apical margin of the third metasomal tergum triangular, with median pointed tooth; pits of the pit row deep and elongate. The other known sub-Saharan member of this group, $C$. nilensis 
(reported here for the first time), has both sexes entirely green to blue; sparser punctation, shallow and largely sparse on scutellum; apex of third tergum with shorter, blunt median tooth. The same diagnostic characters separate $C$. rasnitsyni from all northern African species revised by Linsenmaier (1999).

ETYMOLOGY. The specific epithet rasnitsyni is a patronym honouring Prof. Dr. Alexandr P. Rasnitsyn on the occasion of his 85th birthday and in recognition of his contributions to the study of the Hymenoptera, including Chrysididae.

\section{Chrysis nilensis Linsenmaier, 1959}

Fig. 4A-F

Chrysis leachi [!] var. cyanea du Buysson, 1908: 49, nom. praeocc., nec Linnaeus, 1758. Syntype 우; Egypt: Cairo: Wadi Hoff, leg. R. Père P. Teilhard (MNHN).

Chrysis nilensis Linsenmaier, 1959: 121. Replacement name for Chrysis leachii var. cyanea du Buysson, 1908, nec Linnaeus, 1758.
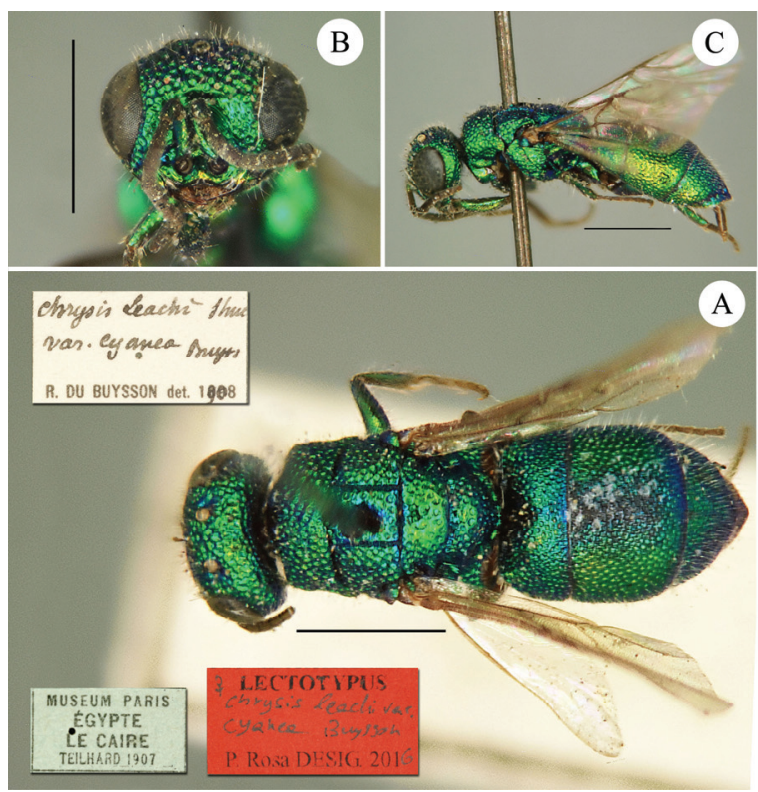

C

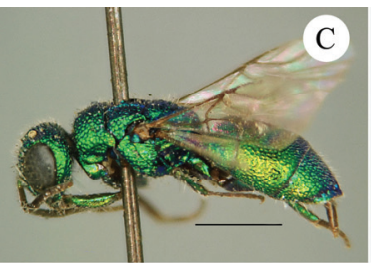

A

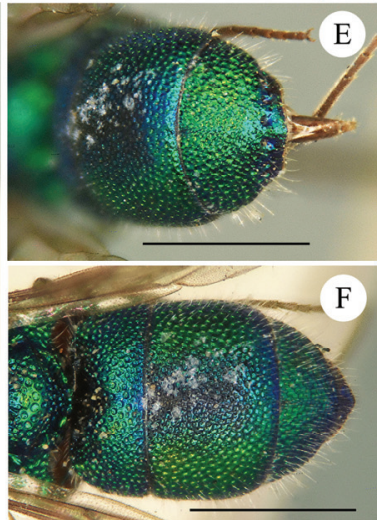

Fig. 4. Chrysis leachi var. cyanea du Buysson, 1908, lectotype, female. A - habitus, dorsal view; B - head, frontal view; C - habitus, lateral view; D - mesosoma, dorsal view; E metasoma, posterior view; $\mathrm{F}$ - metasoma, dorsal view. Scale bars $1.0 \mathrm{~mm}$.

MATERIAL EXAMINED. Lectotype (herein designated) - + , Egypt: Museum Paris Égypte Le Caire Teilhard 1907 // Chrysis leachi [!] Shuc. var. cyanea Buyss. R. du Buysson det. 1908 // + Lectotypus Chrysis leachi var. cyanea Buysson P. Rosa desig. 2016 (MNHN). 1ㅇ, Coll. A. Mochi 10.VI 37 Ezbet El Nakt Egitto // Monochr. leachi [!] cyanea Buyss. det. Zimmermann (NHMW). Sudan: ${ }_{+}$, El Damer Hudeiba 13.1061 leg. R. Remane Staatsslg. München // ᄋ Paratype Chrysis L. afroleachii Lins. det. Linsenmaier 1974 // No type sp. in litteris P. Rosa det. 2010 GBIF-Chrysididae // ex synoptic collection // NML_ENT GBIF_ Chr00022776 (NMLU). Ivory Coast: 19, Odienné C.I. 18.XI 1978 coll. W. Perraudin // ex synoptic collection // NML_ENT GBIF_Chr00022776 (NMLU). 
REMARKS. Chrysis leachi var. cyanea du Buysson, 1908 was described on five female specimens collected by P. Teihlard at Wadi Hoff (Cairo). Linsenmaier (1959) replaced the name, homonym of $C$. cyanea Linnaeus, 1758, with $C$. nilensis and upgraded the taxon to specific rank. Two specimens of $C$. nilensis were found in Linsenmaier's collection, one from Sudan and another one from the Ivory Coast. The presence of C. nilensis in Sudan was expected; in fact, the locality El Damer is located along the Nile river. More interesting is the finding of this species in Ivory Coast. All examined specimens in collections show a noticeably variability in punctation, shape of the apical tooth on the third tergum, and shape of the black spots on the second metasomal sternum. Since Linsenmaier considered the Sudanese specimen a member of a separated species (and proposed the name afroleachii, never published), we here designate the lectotype of $C$. leachi var. cyanea to fix the current interpretation of the species sensu Linsenmaier (1959). An examination of further material is anyway need to evaluate the variability of this taxon in Africa, and eventually proceed with the description of related species.

\section{ACKNOWLEDGEMENTS}

The author is grateful to Marek Halada (České Budějovice, CZ) for sending information on his African material; to Arnošt Kudrna (Rudolfov, CZ) for the pictures of the male of $C$. rasnitsyni; to Marco Bernasconi (NMLU), Claire Villemant and Agnièle Touret-Alby (MNHN) for access to museum collections and examination of type material.

\section{REFERENCES}

Arens, W. 2016. Zwei neue Goldwespen-Arten von griechischen Ägäis-Inseln (Hymenoptera: Chrysididae). Linzer Biologische Beiträge, 48(2): 989-997.

du Buysson, R. 1908. Révision des Chrysidides de l'Égypte. Mémoires de la Société Entomologique d'Égypte, 1: 1-99.

Gerth, M., Franke, F., Stolle, E. \& Bleidorn, C. 2010. Ein neuer Nachweis der Goldwespe Chrysis leachii Shuckard, 1837 (Hymenoptera, Chrysididae) in Thüringen mit Anmerkungen zu potentiellen Wirten. Ampulex, 2: 61-64.

Kimsey, L.S. \& Bohart, R.M. (1991 ["1990"]) The Chrysidid Wasps of the World. Oxford University Press, New York, 652 pp.

Lanes, G.O., Kawada, R., Azevedo, C.O. \& Brothers, D.J. 2020. Revisited morphology applied for Systematics of flat wasps (Hymenoptera, Bethylidae). Zootaxa, 4752(1): 1-127.

Linsenmaier, W. 1959. Revision der Familie Chrysididae (Hymenoptera) mit besonderer Berücksichtigung der europäischen Spezies. Mitteilungen der Schweizerischen Entomologischen Gesellschaft, 32(1): 1-232.

Linsenmaier, W. 1968. Revision der Familie Chrysididae (Hymenoptera). Zweiter Nachtrag. Mitteilungen der Schweizerischen Entomologischen Gesellschaft, 41(1-4): 1-144.

Linsenmaier, W. 1993. Neue Chrysididen von den Kanarischen Inseln (Insecta: Hymenoptera: Chrysididae). Veröffentlichungen aus dem Übersee-Museum Bremen, Naturwissenschaften, 12: 721-732.

Linsenmaier, W. 1994. Beiträge zu Cleptes Latreille, 1802. (Hymenoptera, Chrysididae). Entomofauna, 15 (45): 513-520.

Linsenmaier, W. 1999. Die Goldwespen Nordafrikas (Hymenoptera, Chrysididae). Entomofauna, 10(Supplement): 1-210.

Madl, M. \& Rosa, P. 2012. A Catalogue of the Chrysididae (Hymenoptera: Chrysidoidea) of the Ethiopian Region excluding Malagasy Subregion. Linzer biologische Beiträge, 44(1): $5-169$. 
Pauli, T., Castillo-Cajas, R.F., Rosa, P., Kukowka, S., Berg, A., van den Berghe, E., Fornoff, F., Hopfenmüller, S., Niehuis, M., Peters, R.S., Staab, M., Strumia, F., Tischendorf, S., Schmitt, F. \& Niehuis, O. 2019. Phylogenetic analysis of cuckoo wasps (Chrysididae) reveals the partially artificial nature of the current classification at the genus level in this family of Hymenoptera. Systematic Entomology, 44 (2): 322-335. DOI: https://doi.org/ $10.1111 /$ syen. 12323

Reder, G. \& Arens, W. 2012. Chrysis alcudiae sp. n., a new gold wasp of the Chrysis leachii-group from Mallorca. Mitteilungen des Internationalen Entomologischen Vereins E V Frankfurt, 37(3): 163-172.

Rosa, P. 2006. I Crisidi della Valle d'Aosta. Monografie del Museo Regionale di Scienze Naturali di Saint-Pierre, vol. 6, 394 pp.

Rosa, P., Bernasconi, M.V. \& Wyniger, D. 2015. The Linsenmaier Chrysididae collection housed in the Natur-Museum Luzern (Switzerland) and the main results of the related GBIF Hymenoptera Project (Insecta). Zootaxa, 3986(5): 501-548. DOI: https:// doi.org/10.11646/zootaxa.3986.5.1

Rosa, P., Proshchalykin, M. Yu., Lelej, A.S. \& Loktionov, V.M. 2017a. Contribution to the Siberian Chrysididae (Hymenoptera). Part 1. Far Eastern Entomologist, 341: 1-44.

Rosa, P., Proshchalykin, M. Yu., Lelej, A.S., Loktionov, V.M. \& Mokrousov, M. 2017 b. New records of Chrysididae (Hymenoptera) from Russia with description of five new species. Far Eastern Entomologist, 345: 1-33. 